GRASAS Y ACEITES 65 (4)

October-December 2014, e044

ISSN-L: 0017-3495

doi: http://dx.doi.org/10.3989/gya.0230141

\title{
Influence of the nocturnal harvesting of olives from Salento (Italy) on the quality of the extra virgin olive oil
}

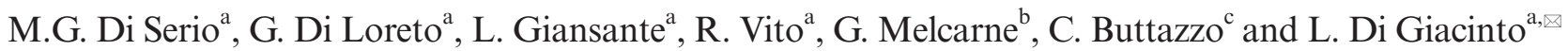

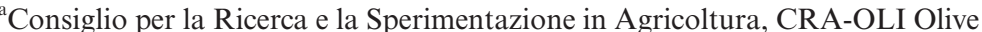 \\ Growing and Oil Industry Research Centre, Città S. Angelo (PE), Italy \\ ${ }^{\mathrm{b}}$ Farm and Oil Mill Forestaforte, Gagliano del Capo (LE), Italy \\ ${ }^{\mathrm{c} C}$ Consultant Agronomist, Lecce, Italy \\ ${ }^{\otimes}$ Corresponding author: luciana.digiacinto@entecra.it
}

Submitted: 19 February 2014; Accepted: 9 June 2014

SUMMARY: In southern Italy, some olive cultivars such as 'Ogliarola Salentina' ripen when the day temperature is still high, at up to 28 to $30^{\circ} \mathrm{C}$. This can affect both the oil quality and the expression of its valuable characteristics. In addition, it increases the risk of undesirable fermentation that can generate off-flavors. In the present study, nocturnal olive harvesting was carried out to determine the influence that temperature can have on the characteristics of the extra virgin olive oil, and particularly on the volatile and oxidative compounds. The data obtained are encouraging: the lower temperatures that occur during the night appear to have a particular and positive impact on the organoleptic characteristics of the extra virgin olive oil produced, with enhanced formation of the volatile compounds that contribute to the 'green' notes of the flavor. In areas where daytime temperatures are very high, the nocturnal harvesting of olives at the correct stage of maturity therefore represents a good agronomic practice for the production of oils with high organoleptic and nutritional merit.

\section{KEYWORDS: Extra virgin olive oil; Nocturnal harvesting; Quality; Volatile substances}

RESUMEN: Influencia de un cosechado nocturno de aceitunas en "Salento" sobre la calidad del aceite de oliva virgen extra. En el sur de Italia, algunas variedades de olivo maduran cuando la temperatura del día sigue siendo alta, hasta $28^{\circ} \mathrm{C}$ a $30^{\circ} \mathrm{C}$. Esto puede perjudicar la calidad del aceite y a la expresión de sus valiosas características, y aumenta el riesgo de fermentación indeseable que puede generar malos sabores. En el presente estudio, la cosecha nocturna de aceitunas se llevó a cabo para determinar la influencia que la temperatura puede tener sobre las características del aceite de oliva virgen extra, y en particular sobre los compuestos volátiles y los compuestos relacionados con la oxidación. Los datos obtenidos son alentadores: las temperaturas más bajas que se producen durante la noche parecen tener un impacto positivo en las características organolépticas del aceite de oliva virgen extra producido, con una mejora de la formación de los compuestos volátiles que contribuyen a las notas "verdes" del sabor. En las zonas donde las temperaturas diurnas son muy altas, la cosecha nocturna de aceitunas, representa, por tanto, una buena práctica agronómica para la producción de aceites con grandes ventajas organoléptica y nutritivas.

PALABRAS CLAVE: Aceite de oliva virgen extra; Calidad; Compuestos volátiles; Cosecha nocturna

Citation/Cómo citar este artículo: Di Serio MG, Di Loreto G, Giansante L, Vito R, Melcarne G, Buttazzo C, Di Giacinto L. 2014. Influence of the nocturnal harvesting of olives from Salento (Italy) on the quality of the extra virgin olive oil. Grasas Aceites 65 (4): e044. doi: http://dx.doi.org/10.3989/gya.0230141.

Copyright: (C) 2014 CSIC. This is an open-access article distributed under the terms of the Creative Commons Attribution-Non Commercial (by-nc) Spain 3.0 Licence. 


\section{INTRODUCTION}

The agricultural and technological choices made throughout the olive-oil sector have important impacts on the quality of the final product. Favorable climatic conditions, plant treatments, olive harvesting at the correct stage of ripeness, fruit picking and storage methods, and the extraction technology applied, definitely affect both the quality and the organoleptic and nutritional characteristics of the resulting olive oil (Angerosa et al., 2001; Angerosa, 2002; Kalua et al., 2007). To achieve the best results, it is necessary to choose the best time for harvesting, which corresponds to the phenological phase of veraison, when the olives have reached their maximum development, and they have the highest concentrations of phenolic substances, reduced water, sugar and acid contents, and maximum oil accumulation.

Furthermore, it is necessary to store olives in perforated boxes, to ensure their correct ventilation and prevent the fermentation processes that can lead to the development of organoleptic defects (i.e., offflavors). Their processing time also has to be as rapid as possible. Indeed, even if most of the enzymes in the olive pulp are active during the phases of crushing and kneading, these can come into contact with polyunsaturated fatty acids, which are produced by lipolytic enzymes during the storage of olives. This is also promoted by high temperatures, prolonged storage periods, and lack of ventilation, which can all result in undesirable fermentation and affect the enzyme activities. This, in turn, encourages an increase in the volatile compounds that are responsible for off-flavors (Kiritsakis et al., 1998; Koprivnjak et al., 2000, 2002).

The features that make extra virgin olive oil unique among the edible fats arise partly from the saponifiable fraction $(98 \%-99 \%)$, but also to a greater extent from the unsaponifiable fraction $(1 \%-2 \%)$. These include compounds that contribute to the olive oil flavor, and other compounds with high nutritional and therapeutic value that are effective natural antioxidants. Among these latter compounds, there are the phenolic substances that result from the degradation of oleuropein and ligstroside, and that contribute to the antioxidant potential of the oil. These also confer the specific organoleptic properties to the oil, and in particular, its bitter and pungent characteristics (Montedoro et al., 1992; Caponio et al., 1999). The volatile compounds that arise from the lipoxygenase pathway are responsible for the aromatic notes of extra virgin olive oil (Angerosa et al., 2000).

Several agronomic parameters can modify the phenolic concentrations. The most extensively studied of these include olive cultivar, fruit ripening, pedoclimatic conditions, agronomic techniques, and the mechanical oil extraction process. In particular, the olive crushing and malaxation are the most important and critical points in the production of oil (Montedoro et al., 1989; Servili et al., 1994, Servili and Montedoro, 2002).

The volatile fraction of olive oil that is obtained from healthy, ripe and correctly stored and processed olives is mainly composed of a number of volatile compounds that are common to the aroma of many fruits and vegetables. It has been suggested that the accumulation of volatile compounds is mainly due to the olive variety, with the climate and other environmental factors apparently having indirect effects through the modification of the degree of olive ripeness (Angerosa et al., 1999). The C-6 aldehydes and alcohols and their acetyl esters that are responsible for the 'green' notes of olive oil can represent up to $80 \%$ of the volatile compounds. Their formation is stimulated in plant cells after the rupture of the cell wall, and regarding the olive fruit, this starts during the milling and continues through the malaxing. The levels of these volatile compounds that remain in the olive oil are a function of the oxidoreductase activity in the fruit, the amount of water, and the time and temperature of the malaxation (Di Giovacchino et al., 2002; Morales and Aparicio, 1999; Preziuso et al., 2009, 2010). The time and temperature of the kneading are two of the main factors that influence the activity of the enzymes that lead to the synthesis of aromas: lipoxygenase and hydroperoxide lyase. In particular, high kneading temperatures (above $30^{\circ} \mathrm{C}$ ) inhibit the actions of these enzymes, and consequently, the formation of volatile compounds that are produced via the lipoxygenase pathway.

In the Italian territories, the harvest period is carried out from mid-October until December, and it is influenced by several factors, including temperature, rainfall, altitude, soil type, and agronomic practices. In Puglia, in southern Italy, the harvest of some olive varieties, such as the 'Ogliarola Salentina o di Lecce' cultivar, is carried out earlier than in the other Italian regions. Here, the high daytime temperatures can affect the oil quality and the expression of certain peculiarities of precious oils, which can lead to the development of fermentation processes that generate off-flavors (Morales et al., 1997, 2005). However, there have been few studies on the effects of temperature during the harvesting, storage and extraction of olive oils, although some studies have investigated the storage of olive fruit under controlled temperatures and atmosphere (Kader et al., 1990; Garcia and Streif, 1991; Kiritsakis et al., 1998; Clodoveo et al., 2007). The storage of olives after harvesting and of the olive oil before it reaches the consumer can change the volatile composition of the olive oil. Storage of the fruit can decrease the aldehyde and ester contents that are responsible for the positive aroma. At the same time, incorrect storage of both the fruit and the oil can produce the volatile compounds that are responsible 
for off-flavors (Kiritsakis et al., 1998; Koprivnjak et al., 2000). There can thus be an absence in the C-6 aldehydes, alcohols and esters that are produced by the lipoxygenase pathway, with increased levels of many aldehydes from chemical oxidation, including hexanal from both chemical and enzymatic reactions, and the consequent characteristic off-flavors of olive oil.

Nocturnal harvesting is a technique that involves targeted viticulture and precision oenology, and it was adopted in 1998 in particular for 'Chardonnay', the first Sicilian variety to ripen in August. During the day, the temperature is high, with it sometimes reaching $35^{\circ} \mathrm{C}$. This increases the risk of undesirable fermentation of grapes during their transport from the vineyard to the cellar, as well as the loss of some aromas during the grape pressing. At night, however, the temperature drops to 16 to $18{ }^{\circ} \mathrm{C}$, which preserves the full aromatic content of the grapes. White grapes are cooled and pressed at a temperature of about $10^{\circ} \mathrm{C}$. This nocturnal harvesting reduces the energy used for cooling the grapes by about $70 \%$, and it is also less tiring for the grape pickers (www.donnafugata.it/pagine/night-harvest. aspx). In Australia and California, USA, nocturnal harvesting has been practiced for 20 years or more, and recently also in southern France, with the help of harvesting machines.

In the present study, nocturnal olive harvesting was carried out to determine the influence that temperature can have on the characteristics of extra virgin olive oil and particularly on the volatile and the related compounds on the oxidation. The olives were harvested at the correct stage of ripeness using good standard practices for a quality product, and they were processed in the Forestaforte oil mill in Gagliano (Lecce, Italy).

\section{MATERIALS AND METHODS}

\subsection{Plant material}

This study was conducted at the Forestaforte oil mill (Gagliano, Lecce, Italy), which is operated in the olive-growing and oil-making sector for the production of top quality extra virgin olive oils (Protected Origin Denomination [D.O.P.] 'Terre d' Otranto') and oils from organic farming. The olives, subjected to two harvest processes, nocturnal and daytime, came from the same plot of land and belong to the cultivar 'Ogliarola Salentina', which is typical of this area. The olive grove, still under investigation, has been subjected to foliar fertilization, four pesticide treatments and one chemical weed. The plants, in addition to being of the same cultivar, were planted at the same time and have been submitted to a similar kind of pruning so as to obtain a homogeneous size of fruits. Both nocturnal and daytime harvesting were consecutively performed when the olives were at the same stage of ripening (veraison $10 \%$ to $15 \%$ ) and had not been attacked by parasites.

Daytime harvesting was carried out from 07:00 hours to 13.00 hours, and nocturnal harvesting from 20:00 hours to 02:00 hours. The average time for storage of the olives in perforated bins ( $300 \mathrm{~kg}$ each) was about $5 \mathrm{~h}$, which was identical for the daytime and nocturnal harvesting. After passage through a defoliator, the total quantity of harvested and processed olives under each of these conditions was approximately $2000 \mathrm{~kg}$ net of impurities (twigs and leaves). The olives have been divided into three aliquots of ca $700 \mathrm{~kg}$ each of which was processed separately (see flowchart in Fig. 1).

To better maintain the temperature of the olives harvested at night, the wash water was cooled to around $10{ }^{\circ} \mathrm{C}$ before the introduction of the olives into the hopper for the start of the machining process. Both of these samples (daytime/ nocturnal harvesting) were processed by an extraction system that used two and half phase centrifugation. This was carried out in the afternoon for daytime harvesting, and early in the morning for nocturnal harvesting.

The olive milling was carried out using a rotary hammer crusher with an $8 \mathrm{~mm}$ diameter hole grid, and malaxation was then performed for a total time of $15 \mathrm{~min}$ with half the volume filling of the kneader (Amenduni) in a series with the hatch open and without the addition of water or heating. The oil yields obtained from each treatment were similar $(13.8 \%$ for the daytime processing, $13.9 \%$ for nocturnal processing). Regarding the hourly productivity and other costs, variations between nocturnal and daytime harvesting were not recorded.

After the extraction, individual oil samples were collected in $250 \mathrm{~mL}$ bottles from the kneader, for a total of six samples (three daytime, three nocturnal), and they were stored at $17{ }^{\circ} \mathrm{C}$. The temperature trends recorded through the collection phase to the conservation of the oil produced are shown in Figure 2.

\subsection{Methods}

The samples of extra virgin olive oil underwent analyses for free acidity, peroxide value, UV spectrophotometric indices, fatty acid and sterol compositions, sensory evaluation, dynamic headspace volatile compounds, alkyl esters, diglycerides, tocopherols and phenolic substances. The index of overall quality (global quality index; GQI) was also calculated, based on 13 variables that describe the nutritional and organoleptic preservation of the extra virgin olive oils (Giansante et al., 2013; Finotti et al., 2007). Duplicate analyses were performed on each sample. 


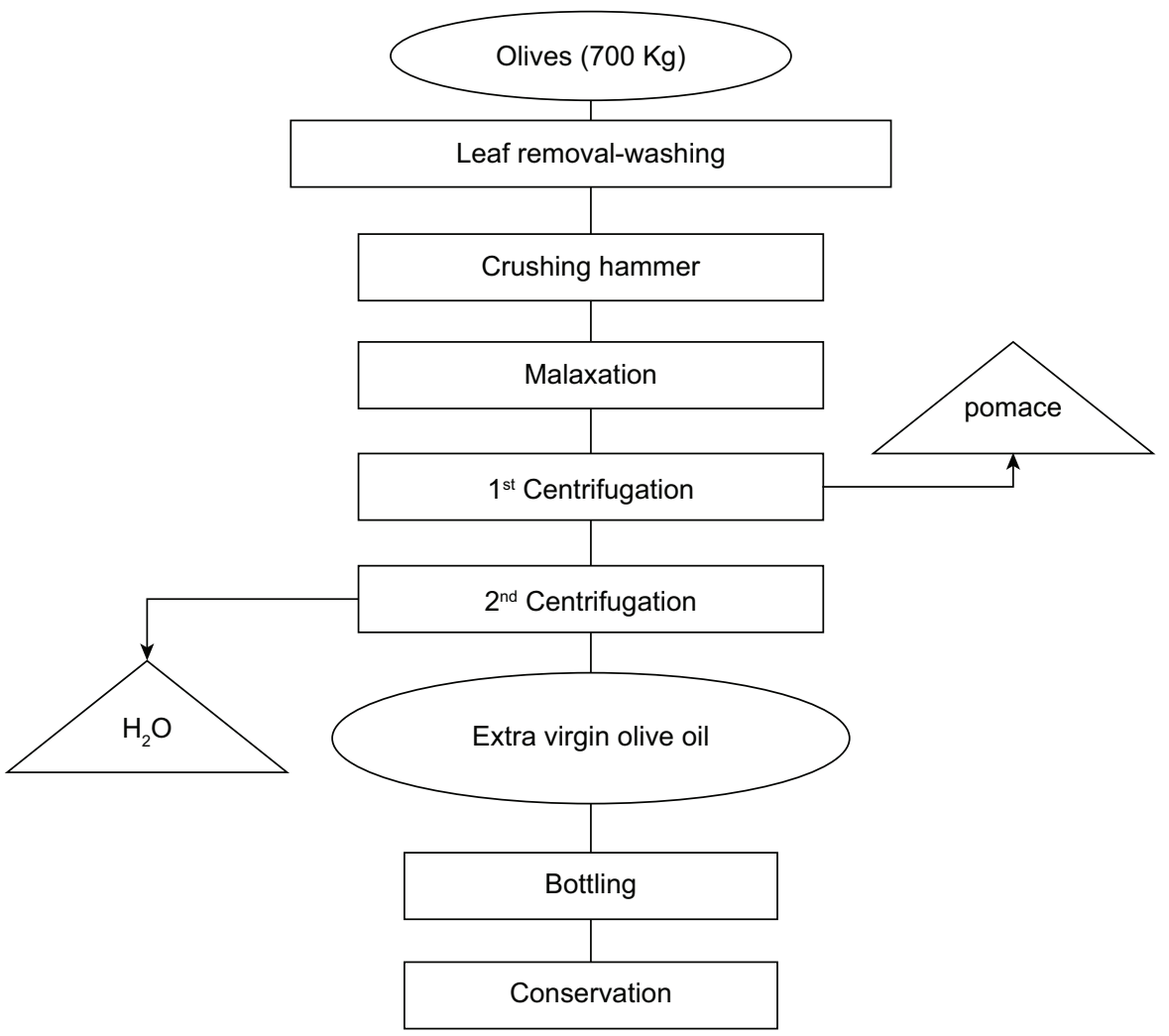

FIGURE 1. Flow diagram of the olive processing.

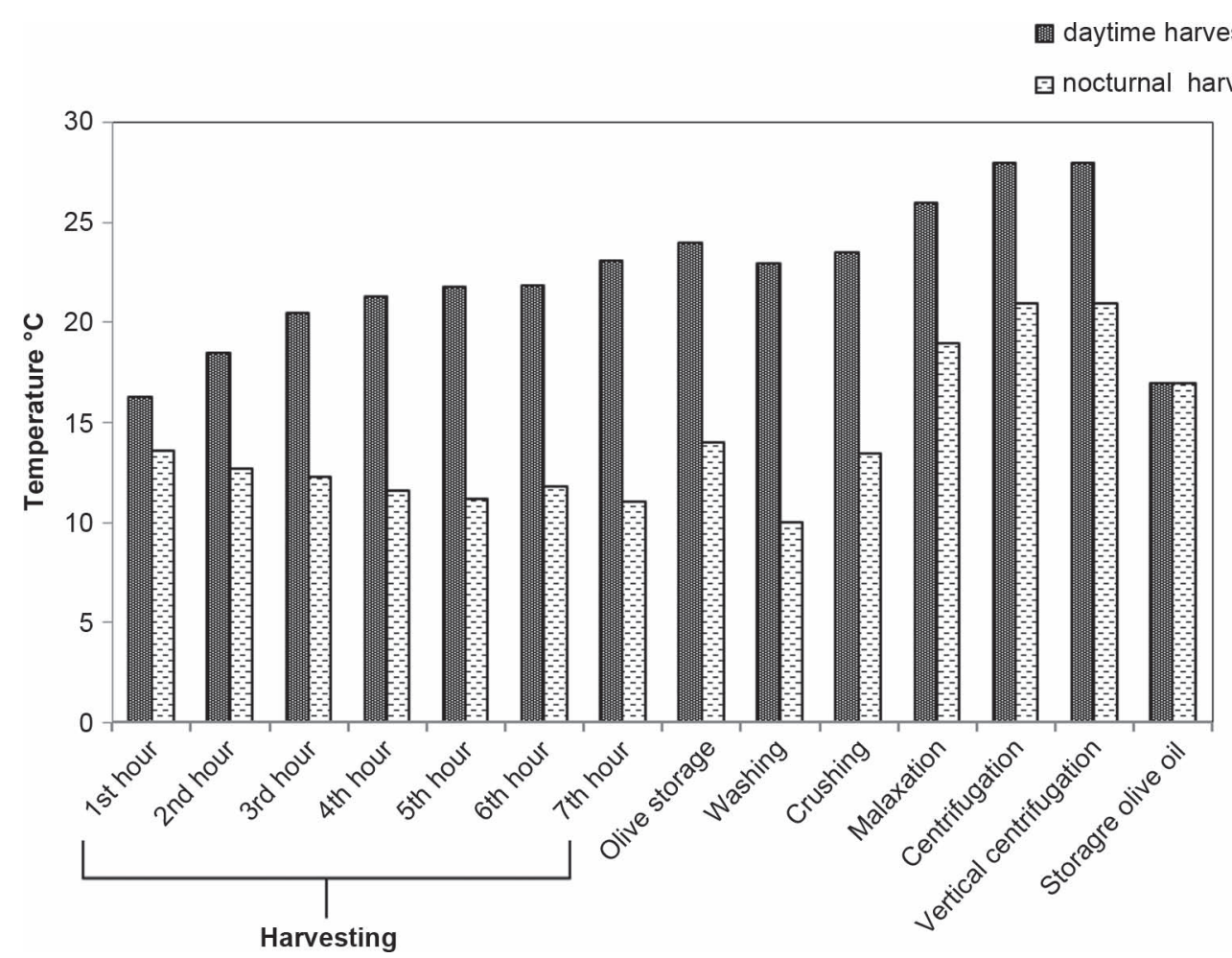

FIGURE 2. Trends in daytime and nocturnal temperature during the olive harvesting and olive oil processing. 


\subsubsection{Free fatty acid content}

The free fatty acid content was determined as the percentage of oleic acid, according to Annex II of the European Union Commission Regulation EEC/2568/91 and its subsequent modifications.

\subsubsection{Peroxide index}

The peroxide index was measured as milliequivalents of active oxygen per kilogram of oil (i.e., $\mathrm{meqO}_{2} / \mathrm{kg}$ oil), as determined according to Annex III of the European Union Commission Regulation EEC/2568/91 and its subsequent modifications (REG. EEC/2568, 1991).

\subsubsection{UV absorption characteristics}

The UV absorption characteristics $\left(K_{232}, K_{270}\right.$, $\Delta \mathrm{K}$ ) were determined according to Annex IX of the European Union Commission Regulation EEC/2568/91 and its subsequent modifications (REG. EEC/2568, 1991).

\subsubsection{Fatty acid composition}

The fatty acid composition was determined according to the method described in the European Union Commission Regulation EEC/2568/91 and its subsequent modifications (Annex X.B) (REG. EEC/2568, 1991).

\subsubsection{Sterol composition}

The sterol composition was determined according to the method described in the European Union Commission Regulation EEC/2568/91 and its subsequent modifications (Annex V) (REG. EEC/2568, 1991).

\subsubsection{Sensory evaluation}

The sensory evaluation was carried out by ten tasters of the CRA-OLI Panel, according to Annex XII of the European Union Commission Regulation EEC/2568/91 and its subsequent modifications (REG. EEC/2568, 1991). The sensorial profile was determined according to COI/T.20/DOC. 22-2005. Nine sensory attributes which can be considered typical for the variety "Ogliarola Salentina" were considered: fruity, bitter, pungent, leafy, grassy, artichoke, bitter almond and chicory. The intensity scale ranged from zero to 10 .

\subsubsection{Dynamic headspace volatile compounds}

The volatile compounds were stripped from 50 $\mathrm{g}$ of oil sample with $\mathrm{N}_{2}\left(1.2 \mathrm{dm}^{3} \mathrm{~min}^{-1}\right.$, for $2 \mathrm{~h}$ at $37^{\circ} \mathrm{C}$ ), using $10 \mathrm{mg}$ nonan-1-ol added as the internal standard. The samples were adsorbed onto $50 \mathrm{mg}$ of activated charcoal and eluted with $1 \mathrm{~mL}$ of diethyl ether. A quantitative analysis was carried out using gas chromatography, with a Carlo Erba Mega Series 5160 gas chromatograph equipped with a Restek Stabil-wax silica capillary column (length, $60 \mathrm{~m}$; i.d., $0.32 \mathrm{~mm}$; film thickness, $0.5 \mu \mathrm{m}$ ), and an oncolumn injection system, a $\mathrm{CO}_{2}$ cryogenic accessory to hold the oven at $28^{\circ} \mathrm{C}$, with the flame Ionization detector set at $230{ }^{\circ} \mathrm{C}$. The oven temperature programme was run at $28^{\circ} \mathrm{C}$ for $6 \mathrm{~min}$, increasing at $1.0^{\circ} \mathrm{C} / \mathrm{min}$ to $33^{\circ} \mathrm{C}$ (no hold), then at $1.8^{\circ} \mathrm{C} / \mathrm{min}$ to $110^{\circ} \mathrm{C}$ (no hold), and then $2.5^{\circ} \mathrm{C} / \mathrm{min}$ to $215^{\circ} \mathrm{C}$, where it was held for $10 \mathrm{~min}$. The carrier gas was $\mathrm{H}_{2}$ at $40 \mathrm{kPa}$. The injection volume was $0.5 \mu \mathrm{L}$. Quantification was by peak area integration with a Carlo Erba Mega Series integrator. Concentrations are expressed as $\mathrm{mg} / \mathrm{kg}$ nonan-1-ol.

\subsubsection{Alkyl esters}

The alkyl esters were determined according to Annex II of the European Union Commission Regulation EU/61/2011 (REG. EU/61, 2011).

\subsubsection{Diglycerides}

The diglycerides were determined according to COI/T.20/Doc. No 32/2013.

\subsubsection{Tocopherols}

For the determination of the tocopherols (Rovellini et al., 1997), a solution of $1 \mathrm{~g}$ olive oil in $10 \mathrm{~mL}$ acetone was used directly for HPLC. $\alpha$-Tocopherol $(0.32 \mu \mathrm{g} / 10 \mu \mathrm{L})$ was used as the external standard. The HPLC analysis was conducted using a high-resolution LC 200 liquid chromatograph, equipped with a Series $200 \mathrm{UV} / \mathrm{Vis}$ detector (Perkin Elmer, Waltham, Massachusetts, USA), a 7725 Rheodyne injector, a $20 \mu \mathrm{L}$ sample loop, and a Totralchrom workstation for data acquisition (Perkin Elmer, Waltham, Massachusetts, USA). Separation on Spherisorb ODS2 (250 x 4.6 mm I.D., $5 \mu \mathrm{m}$; Waters, Milford, MA, USA) was performed at $25{ }^{\circ} \mathrm{C}$ under a constant flow rate of $1 \mathrm{~mL} / \mathrm{min}$ with a mobile phase of $0.2 \%(\mathrm{v} / \mathrm{v}) \mathrm{H}_{3} \mathrm{PO}_{4}$ in water/ methanol/ acetonitrile (2/49/49, v/v/v). The eluted compounds were detected at $292 \mathrm{~nm}$.

\subsubsection{Biophenols}

The phenolic compounds were extracted from the olive oil according to the following method: $2.5 \mathrm{~g}$ of oil were added to $500 \mu \mathrm{L}$ of an internal standard solution $(0.015 \mathrm{mg} / \mathrm{mL}$ syringic acid in methanol). After removal of the methanol under reduced pressure at $<35^{\circ} \mathrm{C}$, the samples were dissolved in $6 \mathrm{~mL}$ hexane and loaded onto solid-phase extraction columns 
(Discovery DSC-DIOL $500 \mathrm{mg}, 3 \mathrm{~mL}$; Supelco, Bellefonte, PA, USA), which were previously conditioned with $6 \mathrm{~mL}$ methanol and $6 \mathrm{~mL}$ hexane. The samples were then washed with $2 \times 3 \mathrm{~mL}$ hexane and $4 \mathrm{~mL}$ hexane/ ethyl acetate $(90 / 10, \mathrm{v} / \mathrm{v})$, and then extracted with $10 \mathrm{~mL}$ methanol. After removal of the methanol in a rotary evaporator at a temperature $<35^{\circ} \mathrm{C}$, the dry residue was taken up with $1 \mathrm{~mL}$ methanol/ water $(1: 1, \mathrm{v} / \mathrm{v})$, filtered through a $0.45 \mu \mathrm{m}$ PVDF membrane, and then injected into the HPLC system. The HPLC analysis of the phenolic extraction was carried out using a high-resolution LC 200 liquid chromatograph, which was equipped with a Series 200 UV/Vis detector (Perkin Elmer, Waltham, Massachusetts, USA), a 7725 Rheodyne injector, and a $20 \mu \mathrm{L}$ sample loop, using a Totralchrom workstation for data acquisition (Perkin Elmer, Waltham, Massachusetts, USA). Separation on Spherisorb ODS2 $(250 \times 4.6 \mathrm{~mm}$ I.D., $5 \mu \mathrm{m}$; Waters, Milford, MA, USA) was performed at $25^{\circ} \mathrm{C}$ at a constant flow rate of $1 \mathrm{~mL} / \mathrm{min}$, with mobile phase mixtures formed from $\mathrm{A}\left(0.2 \%\right.$ [v/v] $\mathrm{H}_{3} \mathrm{PO}_{4}$ in water), $\mathrm{B}$ (methanol) and $\mathrm{C}$ (acetonitrile), as the following ternary gradient programme (as A/B/C, v/v/v): $0 \mathrm{~min}, 96 / 2 / 2 ; 40 \mathrm{~min}$, 50/25/25; $45 \mathrm{~min}, 40 / 30 / 30 ; 60 \mathrm{~min}, 0 / 50 / 50 ; 70 \mathrm{~min}$, 0/50/50; $72 \mathrm{~min}, 96 / 2 / 2 ; 82 \mathrm{~min}, 96 / 2 / 2$. The eluted compounds were detected at $280 \mathrm{~nm}$. Previously, a $20 \mu \mathrm{L}$ external calibration standard (solution of tyrosol $0.030 \mathrm{mg} / \mathrm{ml}$ and syringic acid $0.015 \mathrm{mg} / \mathrm{ml}$ in methanol/water $80 / 20(\mathrm{~V} / \mathrm{V})$ was injected into the HPLC system, to calculate the response factor of syringic acid to tyrosol. Then $20 \mu \mathrm{L}$ samples were injected. Quantification of the phenolic compounds, expressed as tyrosol according to COI/T.20/Doc No $29 / 2009$, was performed according to the concentration of the internal standard and on the basis of the response factor of syringic acid to tyrosol.

\subsection{Global quality index}

The variables extracted from the original data matrix were those most correlated to the organoleptic properties (fruity, bitter, pungency, 1-penten-3one), conservative properties (phenolic substances, tocopherols, peroxide value, free acidity), and nutritional properties (palmitic acid [C16:0], stearic acid [C18:0], oleic acid [C18:1], linoleic acid [C18:2], and the campesterol/stigmasterol ratio). The GQI was calculated through these selected variables, and ranged between 0.0 and 2.0. Three levels of GQI assessment were defined for the olive oils: $0.0<\mathrm{GQI} \leq 1.0$, 'excellent'; $1.0<\mathrm{GQI} \leq 1.6$ 'good'; and $1.6<\mathrm{GQI} \leq 2.0$ 'sufficient' (Giansante et al., 2013; Finotti et al., 2007).

\subsection{Statistical analysis}

The full chemical, chemical-physical, and sensorial data were subjected to statistical analysis using the hierarchical cluster analysis of all of the variables simultaneously. Successively, each variable was analyzed using the Student's t-tests. Data calculations were carried out using the SPSS ${ }^{\circledR}$ software, release 11.5.

\section{RESULTS AND DISCUSSION}

All of the analytical data from the chemical, chemical-physical and sensory analyses were organized into a matrix of $n \times m$, where $n=6$ oils, and $m=77$ analytical variables. Without an a-priori hypothesis, the most straightforward method of hierarchical cluster analysis was applied to the $Z$-scores from the original data. The proximity matrix was calculated according to the squared Euclidean distance, with the furthest neighbor method (or complete linkage) used to combine the clusters. The visual representation of the distances at which the clusters are combined is shown in the dendrogram in Figure 3. The position of the line on the scale indicates the distances at which the clusters are joined. The first vertical line in the dendrogram corresponds to the smallest rescaled distance of oils A1 and A2, which together with oil A3, form a homogeneous cluster of daytime harvesting oils that are well separated from the cluster of the nocturnal harvesting oils B1, B2, B3. This cluster analysis demonstrates the natural conformations of these groups of olive oils (A, B), and in particular the homogeneity within the daytime harvesting samples (A1, A2, A3) and the nocturnal harvesting samples (B1, B2, B3), and the distance between the two groups (A, B), as expected.

\subsection{Quality parameters}

Table 1 gives the mean data for the quality parameters of the two replicates for each of the three samples from each harvesting (daytime, nocturnal). As expected, given the optimal conditions used for their production, the data obtained classify both these oils as top quality extra virgin olive oils, with a high content of natural antioxidants.

For the parameters considered, the 'daytime' and 'nocturnal' oils were not significantly different, except for the diglycerides and the 1,2-diglyceride content, which are parameters that are related to the 'freshness' of olive oil, and to oxidative stress. Indeed, comparing the 'daytime' and 'nocturnal' oils, there were significant differences $(p \leq 0.05)$ for the diglycerides $\left(1.4 \mathrm{~g} \cdot 100 \mathrm{~g}^{-1}\right.$ vs. $1.2 \mathrm{~g} \cdot 100 \mathrm{~g}^{-1}$, respectively), and the 1,2-diglycerides $(95.6 \%$ vs. $98.9 \%$, respectively). Diglycerides are naturally present in extra virgin olive oils, and they derive from the incomplete formation or the partial hydrolysis of triglycerides. The lower value for the nocturnal oil is indicative of lower lipase activity. Conversely, the higher 1.2-diglyceride content (with respect to 1.3-diglycerides) is linked to the greater freshness of the nocturnal oil, due to the olives undergoing less 
Influence of the nocturnal harvesting of olives from Salento (Italy) on the quality of the extra virgin olive oil $\bullet$

Dendrogram using Complete Linkage

Rescaled Distance Cluster Combine
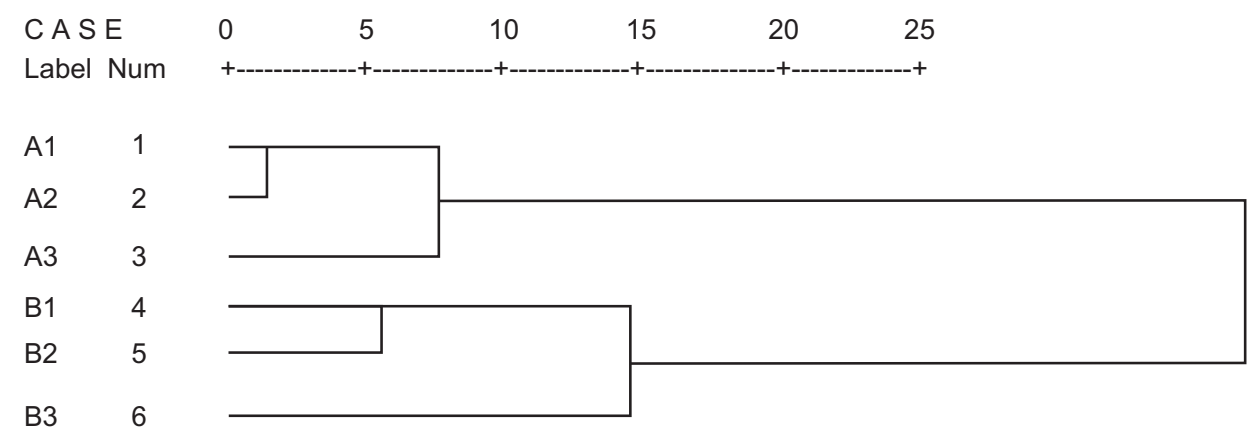

FiguRE 3. Dendrogram from the hierarchical cluster analysis as applied to the Z-scores for the original data from the chemical and sensory analyses, showing the clusters of the olive oil samples.

TABLE 1. Qualitative characteristics of the extra virgin olive oils obtained following daytime and nocturnal harvesting of the olives

\begin{tabular}{|c|c|c|}
\hline \multirow[b]{2}{*}{ Characteristic } & \multicolumn{2}{|c|}{ Harvesting time } \\
\hline & Daytime & Nocturnal \\
\hline Free acidity (\% oleic acid) & $0.21 \pm 0.02$ & $0.19 \pm 0.03$ \\
\hline Peroxide value $\left(\mathrm{meqO}_{2} \cdot \mathrm{kg}^{-1}\right)$ & $6.2 \pm 0.5$ & $5.4 \pm 0.5$ \\
\hline $\mathrm{K}_{232}$ & $1.81 \pm 0.06$ & $1.80 \pm 0.06$ \\
\hline $\mathrm{K}_{270}$ & $0.10 \pm 0.02$ & $0.12 \pm 0.02$ \\
\hline$\Delta \mathrm{K}$ & $-0.002 \pm 0.001$ & $0.000 \pm 0.001$ \\
\hline Alkyl esters $\left(\mathrm{mg} \cdot \mathrm{kg}^{-1}\right)$ & $5 \pm 3$ & $6 \pm 3$ \\
\hline Diglycerides $\left(\mathrm{g} \cdot 100 \mathrm{~g}^{-1}\right)$ & $1.4 \pm 0.1^{*}$ & $1.2 \pm 0.2^{*}$ \\
\hline 1,2-diglycerides $(\%)$ & $95.6 \pm 0.4^{*}$ & $98.9 \pm 0.4^{*}$ \\
\hline Tocopherols $\left(\mathrm{mg} \cdot \mathrm{kg}^{-1}\right)$ & $631 \pm 20$ & $639 \pm 14$ \\
\hline QGI & $1.1 \pm 0.1$ & $1.0 \pm 0.1$ \\
\hline \multicolumn{3}{|l|}{ Organoleptic assessment } \\
\hline median of the fruity attribute & $3.3 \pm 0.3$ & $3.6 \pm 0.3$ \\
\hline median of the bitter attribute & $5.2 \pm 0.1$ & $5.3 \pm 0.3$ \\
\hline median of the pungent attribute & $5.1 \pm 0.3$ & $5.0 \pm 0.3$ \\
\hline median of the defect & $0.0 \pm 0.0$ & $0.0 \pm 0.0$ \\
\hline Total phenols $\left(\mathrm{mg} \cdot \mathrm{kg}^{-1}\right)$ & $746 \pm 81$ & $723 \pm 18$ \\
\hline Secoiridoids $\left(\mathrm{mg} \cdot \mathrm{kg}^{-1}\right)$ & $650 \pm 73$ & $629 \pm 36$ \\
\hline - Low molecular weight $\left(\mathrm{mg} \cdot \mathrm{kg}^{-1}\right)$ & $12 \pm 3$ & $7 \pm 3$ \\
\hline - Medium molecular weight $\left(\mathrm{mg} \cdot \mathrm{kg}^{-1}\right)$ & $313 \pm 39$ & $276 \pm 24$ \\
\hline Ox-forms $\left(\mathrm{mg} \cdot \mathrm{kg}^{-1}\right)$ & $64 \pm 11^{*}$ & $33 \pm 10^{*}$ \\
\hline - High molecular weight $\left(\mathrm{mg} \cdot \mathrm{kg}^{-1}\right)$ & $325 \pm 27$ & $346 \pm 58$ \\
\hline Oleuropein $\left(\mathrm{mg} \cdot \mathrm{kg}^{-1}\right)$ & $167 \pm 6^{*}$ & $215 \pm 44 *$ \\
\hline Ox-forms $\left(\mathrm{mg} \cdot \mathrm{kg}^{-1}\right)$ & $9 \pm 2$ & $8 \pm 2$ \\
\hline Lignans $\left(\mathrm{mg} \cdot \mathrm{kg}^{-1}\right)$ & $10 \pm 7$ & $10 \pm 7$ \\
\hline Other phenols $\left(\mathrm{mg} \cdot \mathrm{kg}^{-1}\right)$ & $86 \pm 13$ & $84 \pm 31$ \\
\hline Total Ox-phenols $\left(\mathrm{mg} \cdot \mathrm{kg}^{-1}\right)$ & $673 \pm 68$ & $682 \pm 29$ \\
\hline
\end{tabular}

*significantly different (2-tailed) for daytime versus nocturnal olive oils, at $p \leq 0.05$. 
oxidative stress and to fewer negative exogenous factors, and in particular, to the lower temperature and the shorter storage time.

These factors also influenced the phenol content of these oils. The phenols were grouped in order to highlight the differences by means of statistical processing of content for the two processes in the following way: low molecular weight secoiridoids (hydroxytyrosol, tyrosol); medium molecular weight secoiridoids (decarboxymethyl oleuropein aglycone dialdehyde form, decarboxymethyl ligstroside aglycone dialdehyde form); oxidized forms of medium molecular weight secoiridoids (decarboxymethyl oleuropein aglycone oxidised dialdehyde form, decarboxymethyl ligstroside aglycone oxidised dialdehyde form); high molecular weight secoiridoids (oleuropein; oleuropein aglycone dialdehyde, aldehyde and hydroxylic forms; ligstroside aglycone dialdehyde, aldehyde and hydroxylic forms); oxidized forms of high molecular weight secoiridoids (oleuropein aglycone oxidized aldehyde and hydroxylic forms; ligstroside aglycone oxidized aldehyde and hydroxylic forms); lignans (pinoresinol, 1 acetoxypinoresinol); other phenols (vanillic acid, caffeic acid, vanillin, para-coumaric acid, hidroxytyrosyl acetate, ferulic acid, ortho-coumaric acid, tyrosyl acetate, cinnamic acid, luteolin, apigenin, methylluteolin). Although the mean total phenol contents of the daytime and nocturnal oils were not statistically different, the mean content of the oxidative form of secoiridoids of medium molecular weight (64 mg $\cdot \mathrm{kg}^{-1}$ vs. $33 \mathrm{mg} \cdot \mathrm{kg}^{-1}$, respectively) and of high molecular weight (as oleuropein; $167 \mathrm{mg} \cdot \mathrm{kg}^{-1}$ vs. $215 \mathrm{mg} \cdot \mathrm{kg}^{-1}$, respectively) were significantly different $(p \leq 0.05)$ between these harvesting times.

The QGI provides a definition of three levels of the overall quality of extra virgin olive oil, as 'excellent' $(0.0<\mathrm{QGI} \leq 1.0)$, 'good' $(1.0<\mathrm{QGI} \leq 1.6)$, and 'sufficient' $(1.6<\mathrm{QGI} \leq 2.0)$. The extra virgin olive oil from the daytime harvesting was classified as 'good', while the extra virgin olive oil from nocturnal harvesting was classified as 'excellent'.

\subsection{Volatile substances and sensory evaluation}

Table 2 shows the mean data obtained from the analysis of the volatile compounds of the head-space from the oils obtained from the daytime harvesting and nocturnal harvesting. Both of these extra virgin olive oils had a high content of 'pleasant' volatile compounds, although these were significantly different (443 vs. $557 \mathrm{mg} \cdot \mathrm{kg}^{-1}$, respectively, $p \leq 0.05$ ). This further confirms the good quality of the olives from which these extractions were made, and the optimal storage conditions used. For the daytime harvesting, the lower content of positive volatile compounds in the olive oil (compared to the nocturnal olive oil) will be due to the negative influence of high temperatures during the harvesting and storage of the olives (Fig. 2). Most of the volatile compounds are formed through the action of the enzymes that are released when the olives are crushed, and these continue to form during malaxation (Olias et al., 1993; Tressl and Drawert, 1973), from enzymatic oxidation through the lipoxygenase pathway. The lipoxygenase pathway is a biochemical reaction scheme for the C-6 aldehydes, alcohols and esters, which are the aroma compounds (Angerosa, 2001; Kiritsakis, 1998). The difference in temperature between the daytime and nocturnal harvesting times, and especially during the malaxation $\left(26{ }^{\circ} \mathrm{C}\right.$ vs. $19{ }^{\circ} \mathrm{C}$, respectively), is reflected in the levels of the main volatile compounds that are responsible for the green notes of the flavor of extra virgin olive oil. There were significant differences among these main volatile compounds, in terms of 3-methylbutanal, 2-butanone, trans-2-penten-1-ol, cis-2-penten-1-ol, trans-2-hexenyl acetate, 1-hexanol and cis-3-hexen1-ol. As can be seen from the data in Table 2, these principal compounds of the lipoxygenase pathway were at higher levels for the nocturnal harvesting because these are influenced by the activity of the enzymes in the olives.

The maximum activities of the lipoxygenase enzymes occur in the temperature range from 25 to $35^{\circ} \mathrm{C}$ (Ridolfi et al., 2002), while hydroperoxide lyase is relatively labile, with an optimum activity at around $15^{\circ} \mathrm{C}$, and maximum activity at about $35^{\circ} \mathrm{C}$ (Anthon and Barret, 2003, Salas and Sánchez, 1999). These factors result in the loss of flavor for oil obtained when the processing is performed at higher temperatures. These differences in the compounds responsible for the green notes also resulted in different sensory profiles for these two types of extra virgin olive oil (Fig. 4): for the olive oil produced following night-time harvesting (the nocturnal oil), the perception of fruity, leafy, grassy, artichoke, bitter almond and chicory notes was greater. There were also significant differences $(p \leq 0.05)$ between the daytime and nocturnal oils for some of the compounds responsible for off-flavors: propyl acetate, pentanal and 2-penthylfuran (Table 2). As it appears that olive storage at higher temperatures before oil processing promotes an increase in such undesirable compounds (Koprivnjak et al., 2000), this is to be avoided in the production of extra virgin olive oil. Also, good practice in olive handling recommends that the olives are processed as soon as possible after harvesting, and to avoid prolonged storage periods (Di Giovacchino et al., 2002; Kalua et al., 2007).

\section{CONCLUSIONS}

The data obtained in the present study for the daytime and nocturnal harvesting of olives demonstrate that: 
Influence of the nocturnal harvesting of olives from Salento (Italy) on the quality of the extra virgin olive oil $\bullet 9$

TABLE 2. Levels of volatile compounds and sensory descriptors of the extra virgin olive oils obtained following daytime and nocturnal harvesting of the olives

\begin{tabular}{|c|c|c|c|}
\hline \multirow[b]{2}{*}{ Volatile compound } & \multicolumn{2}{|c|}{ Harvesting time } & \multirow[b]{2}{*}{ Sensory description** } \\
\hline & Daytime & Nocturnal & \\
\hline Ethyl acetate & $10 \pm 2$ & $10 \pm 1$ & Slightly bitter/ pungent, sweet, aromatic \\
\hline 2-Butanone & $4.0 \pm 0.4^{*}$ & $1.4 \pm 0.4^{*}$ & Tomato, apple \\
\hline 2-Methylbutanal & $0.50 \pm 0.01$ & $0.29 \pm 0.01$ & Apple, malty, sweet, fruity \\
\hline 3-Methylbutanal & $0.5 \pm 0.1 *$ & $0.2 \pm 0.1 *$ & Apple, malty, sweet, fruity \\
\hline Iso-propanol & $0.3 \pm 0.2$ & $0.3 \pm 0.2$ & \\
\hline 2-Ethylfuran & $4.2 \pm 0.3$ & $4.7 \pm 0.8$ & Sweet \\
\hline Pentene dimers & $3.7 \pm 0.6$ & $3.9 \pm 0.5$ & \\
\hline 2-Pentanone & $18 \pm 3^{*}$ & $19 \pm 3^{*}$ & \\
\hline Propyl acetate & $1.7 \pm 0.50 *$ & $0.6 \pm 0.5^{*}$ & \\
\hline Pentanal & $0.17 \pm 0.02 *$ & $0.09 \pm 0.01 *$ & Woody, bitter, oily \\
\hline alfa-Pinene & $11.8 \pm 0.7$ & $13.1 \pm 1.7$ & \\
\hline Iso-butyl acetate & $0.7 \pm 0.1$ & $0.9 \pm 0.2$ & \\
\hline 1-Penten-3-one & $20 \pm 1$ & $22 \pm 2$ & Green, pungent \\
\hline 2-Butanol & $17 \pm 3$ & $16 \pm 5$ & Fusty, muddy, winey \\
\hline 3-Hexanone & $0.20 \pm 0.09$ & $0.37 \pm 0.06$ & \\
\hline Hexanal & $28 \pm 5$ & $36 \pm 5$ & Sweet, apple, green, fruity, grassy \\
\hline 3-Pentanol & $0.10 \pm 0.05$ & $0.11 \pm 0.02$ & \\
\hline 1-Penten-3-ol & $32 \pm 4$ & $37 \pm 5$ & Fruity, wet earth \\
\hline cis-3-Hexenal & $1.7 \pm 0.8$ & $2.2 \pm 0.8$ & Green, leaf-like \\
\hline 3-Methyl-1-butanol & $4.2 \pm 0.3$ & $4.6 \pm 0.9$ & Fusty \\
\hline trans-2-Hexenal & $175 \pm 17$ & $200 \pm 32$ & Bitter almonds, green, apple-like, green astringent \\
\hline 2-Penthylfuran & $12.5 \pm 0.8^{*}$ & $14.8 \pm 0.9^{*}$ & \\
\hline 1-Pentanol & $2.5 \pm 0.7$ & $2.3 \pm 0.8$ & \\
\hline 3-Octanone & $0.10 \pm 0.04$ & $0.02 \pm 0.02$ & Rancid \\
\hline Hexyl acetate & $7.6 \pm 0.7$ & 9.30 .7 & Green grassy, sweet, fruity \\
\hline 2-Octanone & $0.10 \pm 0.01$ & $0.16 \pm 0.5$ & Undesirable, mould, green \\
\hline Octanal & $2.8 \pm 0.5$ & 2.8 .5 & Fatty, sharp, citrus-like \\
\hline trans-2-Penten-1-ol & $0.47 \pm 0.06^{*}$ & $0.23 \pm 0.09^{*}$ & Desirable \\
\hline cis-3-Hexenyl acetate & $2.1 \pm 0.3$ & $2.3 \pm 0.2$ & Green, banana-like \\
\hline cis-2-Penten-1-ol & $60 \pm 1^{*}$ & $96 \pm 8^{*}$ & Green grass, banana-like \\
\hline trans-2-Eptenal & $0.4 \pm 0.2$ & $0.30 \pm 0.1$ & Rancid, tallowy, pungent \\
\hline trans-2-Hexenyl acetate & $1.0 \pm 0.2 *$ & $2.3 \pm 0.3^{*}$ & \\
\hline 6-Methyl-5-hepten-2-one & $0.13 \pm 0.04$ & $0.12 \pm 0.06$ & Rancid, Musty, Bitter taste (dried green herbs), pungent, green \\
\hline 1-Hexanol & $12.3 \pm 0.5^{*}$ & $17.6 \pm 0.5^{*}$ & Fruity, banana, soft \\
\hline trans-3-Hexen-1-ol & $0.35 \pm 0.05$ & $0.53 \pm 0.09$ & Green leafy, nuts \\
\hline cis-3-Hexen-1-ol & $35 \pm 8^{*}$ & $66 \pm 8^{*}$ & Green banana, leaf-like \\
\hline Nonanal & $2.9 \pm 0.5$ & $2.0 \pm 0.5$ & Fatty, waxy, pungent \\
\hline trans-2-Hexen-1-ol & $11 \pm 2$ & $9 \pm 1$ & Green (cut green grassy) \\
\hline Acetic acid & $0.24 \pm 0.09$ & $0.1 \pm 0.1$ & Sour, vinegary, vinegar-like \\
\hline trans-2-Nonenal & $0.30 \pm 0.02$ & $0.28 \pm 0.07$ & Paper-like, fatty, undesirable \\
\hline Propionic acid & $4.7 \pm 0.8$ & $2.3 \pm 0.8$ & Undesirable \\
\hline Total 'positive flavors' & $443 \pm 28^{*}$ & $557 \pm 22^{*}$ & \\
\hline Total 'off-flavors' & $173 \pm 11$ & $143 \pm 12$ & \\
\hline
\end{tabular}

*significantly different (2-tailed) for daytime versus nocturnal olive oils, at $p \leq 0.05$.

**(Aparicio et al., 1994, 1996 and Aparicio and Luna 2002; Blekas et al., 1993; Di Giacinto et al., 2010; Morales et al., 1995; Reiners and Grosch 1998). 


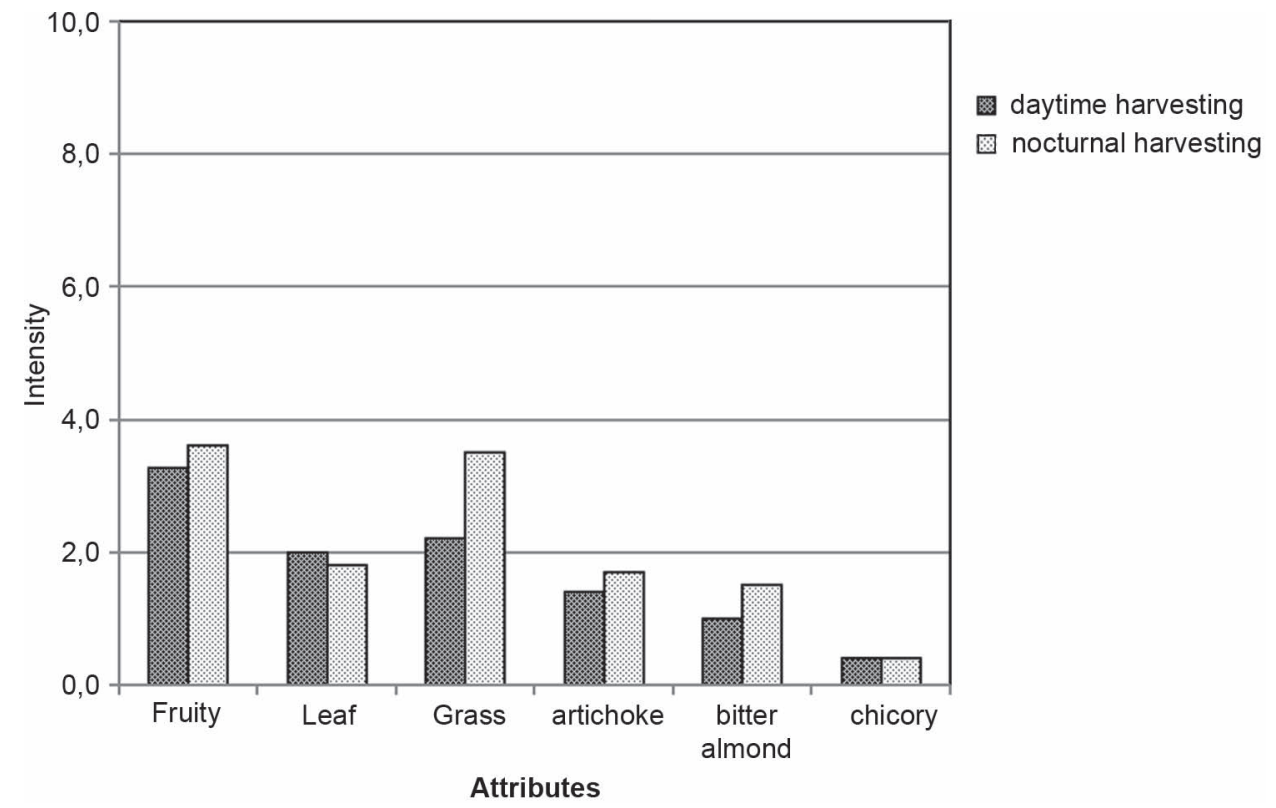

FIGURE 4. Sensory profile of the extra virgin olive oils derived following daytime and nocturnal harvesting.

(i) The oil yields obtained by each treatment are similar $(13.8 \%$ by the daytime processing, $13.9 \%$ by nocturnal processing). Regarding the hourly productivity and other costs, variations between nocturnal and daytime harvesting were not recorded.

(ii) The time and temperature of the storage of olives, and the extraction temperature for the olive oil, are the most important aspects for the quality and the particular characteristics of extra virgin olive oil.

(iii) The lower temperatures during nocturnal harvesting of the olives and during the oil extraction have positive effects on some of the quality characteristics of extra virgin olive oil, and in particular, on compounds that are negatively related to oxidative processes.

(iv) The time and temperature of the storage of olives after harvesting and during the extraction of the oil also influence the levels of volatile compounds from the lipoxygenase pathway (the green flavors) and the off-flavor composition of the extra virgin olive oil.

\section{REFERENCES}

Angerosa F. 2002. Influence of volatile compounds on virgin olive oil quality evaluated by analytical approaches and sensor panels. Eur. J. Lipid Sci. Technol. 104, 639-660. http://dx.doi. org/10.1002/1438-9312(200210)104:9/10<639::AIDEJLT639>3.0.CO;2-U.

Angerosa F, Basti C, Vito R. 1999. Virgin olive oil volatile compounds from lipoxygenase pathway and characterization of some Italian cultivars. J. Agr. Food Chem. 47, 836-839. http://dx.doi.org/10.1021/jf980911g.
Angerosa F, Mostallino R, Basti C, Vito R. 2000. Virgin olive oil odour notes: their relationships with volatile compounds from the lipoxygenase pathway and secoiridoid compounds. Food Chem. 68, 283-287. http://dx.doi. org/10.1016/S0308-8146(99)00189-2.

Angerosa F, Mostallino R, Basti C, Vito R. 2001. Infuence of malaxation temperature and time on the quality of virgin olive oils. Food Chem. 72, 19-28. http://dx.doi.org/10.1016/ S0308-8146(00)00194-1.

Anthon G, Barret DM. 2003. Thermal inactivation of lipoxygenase and hydroperoxytrienoic acid lyase in tomatoes. Food Chem. 81, 275-279. http://dx.doi.org/10.1016/ S0308-8146(02)00424-7.

Aparicio R, Alonso MV, Morales MT, Calvente J. 1994. Relationship between the COI and other sensory profiles by statistical procedures. Grasas Aceites. 45, 26-41. http:// dx.doi.org/10.3989/gya.1994.v45.i1-2.976.

Aparicio R, Morales MT, Alonso MV. 1996. Relationship between volatile compounds and sensory attributes of olive oils by the sensory wheel. J. Am. Oil Chem. Soc. 73 , 1253-1264. http://dx.doi.org/10.1007/BF02525454.

Aparicio R, Luna G. 2002. Characterisation of monovarietal virgin olive oils. Eur. J. Lipid Sci. Technol. 104, 614-627. http:/l dx.doi.org/10.1002/1438-9312(200210)104:9/10<614::AIDEJLT614>3.0.CO;2-L.

Blekas G, Guth H. 1993. Evaluation and quantification of potent odorants of Greek virgin olive oils. In Food Flavors, Generation Analysis and Process Influence. Charalampous $\mathrm{G}$ (Ed.), Elsevier, 419-427.

Caponio F, Alloggio V, Gomes T. 1999. Phenolic compounds of virgin olive oil: influence of paste preparation techniques. Food Chem. 64, 203-209. http://dx.doi.org/10.1016/ S0308-8146(98)00146-0.

Clodoveo ML, Delcuratolo D, Gomes T, Colelli G. 2007. Effect of different temperatures and storage atmospheres on Coratina olive oil quality. Food Chem. 102, 571-576. http:// dx.doi.org/10.1016/j.foodchem.2006.05.035.

COI/T.20/DOC.22. 2005. Method for the organoleptic assessment of extra virgin olive oil applying to use a designation of origin. Madrid, Spain: International Olive Oil Council.

COI/T.20/DOC.29. 2009. Determination of biophenols in olive oils by HPLC. Madrid, Spain: International Olive Oil Council. 
COI/T.20/DOC.32. 2013. Determination of composition of triacylglycerols and composition and content of diacylglycerols by capillary gas chromatography, in vegetables oils. Madrid, Spain: International Olive Oil Council.

Commission Regulation EU No 61/2011 of 24 January 2011 amending Regulation (EEC) No 2568/91 on the characteristics of olive oil and olive-residue oil and on the relevant methods of analysis.

Di Giacinto L, Di Loreto G, Di Natale C, Gianni G, Guasti S, Migliorni M, Pellegrino M, Perri E, Santonico M. 2010. Caratterizzazione analitica degli attributi sensoriali degli oli vergini di oliva (Aromolio). Ed C.C.I.A.A. Firenze.

Di Giovacchino L, Sestili S, Di Vincenzo D. 2002. Influence of olive processing on virgin olive oil quality. Eur. J. Lipid Sci. Technol. 104, 587-601. http://dx.doi.org/10.1002/14389312(200210)104:9/10<587::AID-EJLT587>3.0.CO;2-M

Finotti E, Bersani A.M, Bersani E. 2007. Total quality indexes for extra -virgin oli oils. J. Food Quality 30, 911-931. http:// dx.doi.org/10.1111/j.1745-4557.2007.00159.x.

Giansante L, Di Loreto G, Di Giacinto L, Valentini M. 2013. Indice globale di qualità (IGQ): organolettica, conservativa e nutrizionale. Formulazione chemiometrica mediante descrittori analitici e sensoriali di oli di oliva extra vergini prelevati nella provincia di Arezzo. Acta Italus Hortus 10, 285-292.

Garcia JM, Streif J. 1991. The Effect of Controlled Atmosphere Storage on Fruit and Oil Quality of "Gordal" Olives, Gartenbauwissenschaft 56, 233-238.

Kader AA, Nanos GD, Kerbel EL. 1990. Storage Potential of Fresh Manzanillo Olives. Calif. Agric. 44, 23-24.

Kalua CM, Allen MS, Bedgood DR, Bishop AG, Prenzler PD, Robards K. 2007. Olive oil volatile compounds, flavor development and quality: A critical review. Food Chem. 100, 273-286. http://dx.doi.org/10.1016/j. foodchem.2005.09.059.

Kiritsakis AK. 1998. Flavor components of olive oil review. $J$. Am. Oil Chem. Soc. 75, 673-680. http://dx.doi.org/10.1007/ s11746-998-0205-6.

Kiritsakis A, Nanos GD, Polymenopoulos Z, Thomai T, Sfakiotakis EM. 1998. Effect of fruit storage conditions on olive oil quality. J. Am. Oil Chem. Soc. 75, 721-724. http:// dx.doi.org/10.1007/s11746-998-0212-7.

Koprivnjak O, Procida G, Zelinotti T. 2000. Changes in the volatile components of virgin olive oil during fruit storage in aqueous media. Food Chem. 70, 377-384. http://dx.doi. org/10.1016/S0308-8146(00)00107-2.

Koprivnjak O, Conte L, Totis N. 2002. Influence of Olive Fruit Storage in Bags on Oil Quality and Composition of Volatile Compounds. Food Technol. Biotechnol. 40, 129-134.

Montedoro GF, Garofolo L, Bertuccioli M, Pannelli G. 1989. Influence of the cultivars and pedoclimatic conditions on the virgin olive oil quality. Proceedings of 6th International Flavor Conference, Greece. Ed. G. Charalambous, Elsevier Science Publishers B.V. Amsterdam, 881-891.

Montedoro GF, Servili M, Baldioli M, Miniati E. 1992. Simple and hydrolyzable phenolic compounds in virgin olive oil. Initial characterization of the hydrolyzable fraction. J. Agric. Food Chem. 40, 1577-1580. http://dx.doi. org/10.1021/jf00021a020.
Morales MT, Alonso MV, Rios JJ, Aparicio R. 1995. Virgin olive oil aroma: relationship between volatile compounds and sensory attributes by chemometrics. J. Agric. Food Chem. 43, 2925-2931. http://dx.doi.org/10.1021/jf00059a029.

Morales MT, Aparicio R. 1999. Effect of Extraction Conditions on Sensory Quality of Virgin Olive Oil. J. Am. Oil Chem. Soc. 76, 295-300. http://dx.doi.org/10.1007/s11746999-0234-9.

Morales MT, Luna G, Aparicio R. 2005. Comparative study of virgin olive oil sensory defects. Food Chem. 91, 293-301. http://dx.doi.org/10.1016/j.foodchem.2004.06.011.

Morales MT, Rios JJ, Aparicio R. 1997. Changes in the volatile composition of virgin olive oil during oxidation: flavors and off-flavors. J. Agric. Food Chem. 45, 2666-2673. http:// dx.doi.org/10.1021/jf960585+.

Olias J M,Perez AG, Rios JJ, Sanz, LC. 1993. Aroma of virgin olive oil: biogenesis of the "green" odor notes. J. Agric. Food Chem. 41, 2368-2373. http://dx.doi.org/10.1021/ jf00036a029.

Preziuso SM, Di Serio MG, Biasone A, Vito R, Mucciarella MR, Di Giovacchino L. 2009. Effetti dei differenti metodi di frangitura delle olive sulla resa e sulle caratteristiche qualitative dell'olio vergine di oliva. Atti del Convegno Nazionale Dell'Olivo e dell'Olio. Portici, pag 71.

Preziuso SM, Di Serio MG, Biasone A, Vito R, Mucciarella MR, Di Giovacchino L. 2010. Influence of olive crushing methods on the yields and oil characteristics. Eur. J. Sci. Technol. 112, 1345-1355. http://dx.doi.org/10.1002/ ejlt.201000303.

REG. EEC/2568 (1991). Consolidated version of the Commission Regulation EEC No 2568/91 of 11 July 1991 on the characteristics of olive oil and olive-residue oil and on the relevant methods of analysis, http://eurlex.europa. eu/LexUriServ/LexUriServ.do?uri=CONSLEG:1991R256 8:20110401:EN:PDF

Reiners J, Grosch W. 1998. Odorants of virgin olive oils with different flavor profiles. J. Agric. Food Chem. 46, 2754-2763. http://dx.doi.org/10.1021/jf970940b.

Ridolfi M, Terenziani S, Patumi M, Fontanazza G. 2002. Characterization of the lipoxygenase in some olive cultivars and determination of their role in volatile compounds formation. J. Agric. Food Chem. 50, 835-839. http://dx.doi. org/10.1021/jf0109118.

Rovellini P, Azzolini M, Cortesi N. 1997. Tocoferoli e tocotrienoli in oli e grassi vegetali mediante HPLC. Riv. It. Sost. Grasse 74, 1-5.

Salas JJ, Sánchez J. 1999. Hydroperoxide lyase from olive (Olea europaea) fruits. Plant Science. 143, 19-26.

Servili M, Baldioli M, Montedoro GF. 1994. Phenolic composition of virgin olive oil in relationship to some chemical and physical aspects of malaxation. Acta Horticolturae. 356, 331-336.

Servili M, Montedoro GF. 2002. Contribution of phenolic compounds to virgin olive oil quality. Eur. J. Lipid Sci. Technol. 104, 602-613. http://dx.doi.org/10.1002/14389312(200210)104:9/10<602::AID-EJLT602>3.0.CO;2-X.

Tressl R, Drawert F. 1973. Biogenesis of banana volatiles. $J$. Agric. Food Chem. 21, 560-565. http://dx.doi.org/10.1021/ jf60188a031. 